2016-07

\title{
What future for the Global Aid for Trade Initiative? Towards an assessment of its achievements and limitations
}

\section{Hynes, W}

http://hdl.handle.net/10026.1/5126

\subsection{1/dpr.12165 \\ Development Policy Review \\ Wiley}

All content in PEARL is protected by copyright law. Author manuscripts are made available in accordance with publisher policies. Please cite only the published version using the details provided on the item record or document. In the absence of an open licence (e.g. Creative Commons), permissions for further reuse of content should be sought from the publisher or author. 
What future for the Global Aid for Trade Initiative? Towards an assessment of its achievements and limitations

\section{William Hynes and Patrick Holden}

This is an Accepted Manuscript of an article published by Wiley in Development Policy Review (Nolume 34, Issue 4 July 2016) available at: DOI: 10.1111/dpr.12165

A link to the full published version can be found here:

http://onlinelibrary.wiley.com/doi/10.1111/dpr.12165/abstract 
What future for the Global Aid for Trade Initiative? Towards an assessment of its achievements and limitations

\section{Introduction}

The global Aid for Trade/AfT Initiative was launched under the auspices of the WTO in 2006 to develop synergies between trade policy and development aid. Trade has long been considered a potential stimulus to economic growth. Trade can promote specialisation, competition that reduces costs of production, access to products, services, knowledge and technologies that would otherwise be unavailable for less developed economies. However, the precise link between trade and development has been a controversial topic (Page, 2006). Trade policy including multilateral and regional trade agreements and enhanced market access, while necessary is not sufficient to promote growth and development. A broader range of factors need to be considered, chief among them is capacity to trade, and the human and institutional capacity constraints that need to be overcome. Development partners and multilateral agencies have focused on how aid (concessional as well as non-concessional development finance) could help countries take advantage of market access. Broadly speaking AfT consists of actions to facilitate trade, including through building capacity to negotiate agreements and implement them, investing in infrastructure to lower trade and transport costs that helps producers to connect to markets, and funding adjustment programmes to help domestic producers adapt to new trade possibilities. The 2006 Initiative outlined the principles, categories and procedures for this form of aid and the OECD and WTO Secretariats were primarily charged with monitoring the implementation of these principles by partner countries, donor agencies and the providers of south-south trade-related co-operation. There has been much criticism of this Initiative. In recent papers Stiglitz and Charlton (2012) argue that it has failed, while Hallaert also argues that the AfT process has run its course (Hallaert, 2013). This article argues for a more nuanced and realistic judgement on the AfT Initiative. The argument is based on a detailed consideration of the precise objectives of this particular Initiative and a broader (theoretical and empirical) understanding of the possibilities for any contemporary international development aid initiative. Much of the debate on AfT has been, understandably, coloured by resentment of the historical iniquities of the international trade and economic system. However, it was not realistic to expect this particular Initiative to resolve all of these and there is a danger that unrealistically high expectations could lead to the baby being thrown out with the bathwater. The Initiative, which has substantial achievements to its credit, is now challenged by general developments in international aid governance, but this is a reason to redouble its positive elements rather than abandon it.

The article begins with a brief summary of the AfT agenda before moving on to a theoretical discussion of the challenges to international co-operation in the field of development. A clear and explicit understanding of the limitations of contemporary global governance is needed for us to fairly evaluate any given initiative. It is crucial to note the distinction here between the international trade system (with formal legally binding commitments) and the more informal methods of international aid governance. Many, particularly those based in the trade policy community, would have liked the Initiative to involve rigorous legally binding financial pledges but there was no way that 
developed countries would agree to formal legal commitments in aid policy. Instead the AfT Initiative adopted and adapted techniques and processes from best practice models of co-operation in a complex non-hierarchical system, such as the international aid community. However, the fact that the initiative is based on more informal norm promotion rather than legal commitments may be at the heart of many people's dissatisfaction with the AfT regime. The article then outlines the monitoring process in some detail and analyses the evolving review process. Finally it offers a comprehensive analysis of the achievements and limitations of the agenda thus far, including the question of aid additionality (raised by Stiglitz and Charlton) as well as its broader impact on the conception and practice of aid, trade and development policy. This empirical analysis focuses on the period from 2006 to 2013. The final sections consider the contemporary challenges to AfT, and development aid more generally, concluding with a discussion of the lessons learnt from the experience of this Initiative and the outlook for the future.

\section{Background}

The Aid for Trade agenda was the outcome of a long and intense debate on the responsibilities of developed countries, who sought a new round of trade liberalisation, to help developing countries and least developed countries in particular (Wilkinson, 2006). The WTO Hong Kong Ministerial in 2005 led to the creation of a new WTO work programme on Aid for Trade. It mandated the creation of a WTO Task Force to provide recommendations on i.) how to operationalize Aid for Trade, and ii) how Aid for Trade might contribute most effectively to the development dimension of the Doha Development Agenda. The Task Force was comprised of developed countries (including the EU), developing countries and developing country institutions, such as the LDC group. International organisations acted in an advisory role to the Task Force, on request. The WTO recognised that the support of the IMF, World Bank, regional development banks, the Organization for Economic Co-operation and Development/OECD and other relevant international agencies was essential (WTO, 2006a). 22 official submissions were made (by states and international organizations) to the Task Force. ${ }^{1}$ Some developing country groupings were supportive of a new, dedicated Aid for Trade fund. The African Development Bank/AfDB, for example, suggested a new global Aid for Trade fund or facility to be based at the AfDB (African Development Bank, 2006). However, the donors in the WTO Task Force were very much against creating a new fund or institution and so this path was not taken.

Beyond the official procedure the Task Force process generated a broader debate about AfT with input from WTO members, international organisations and the academic community. ${ }^{2}$ It had previously been argued that

\footnotetext{
${ }^{1}$ There were communications from 10 International Organisations, 5 WTO Groups ( 2 from the LDC Group) and 7 countries or groups of countries (WTO Secretariat records).

${ }^{2}$ Even before the Task Force was established and with expectations high of an imminent conclusion to the Doha Round there was considerable debate on Aid for Trade-related adjustment. Neilson (2005) stated that countries suffering adjustment shocks from trade liberalization, including the Doha round, needed to be assured of transition support from the international community. Hoekman and Prowse (2005) argued that rather than creating a fund to compensate for preference erosionit would be more efficient and effective to integrate funding to offset preference erosion into the broader AfT effort,
} 
enhancing trade capacities required concerted action outside the WTO (Hoekman, 2002) while Stiglitz and Charlton (2006) suggested a multilateral fund for Aid for Trade and also called for aid commitments to be enforceable within the WTO system with charges of non-compliance brought against any country not meeting its AfT commitments. Zedillo and others (2005) also called for the creation of a dedicated AfT mechanism. The World Bank/IMF (2005) had supported increased funding trade-related and infrastructural reforms, but were against the creation of a new and dedicated multilateral fund. The OECD (2006a) argued that multilateral funds were good at generating resources but not good at disbursing them. They also highlighted the contradiction between creating a new fund and the Paris Principles on national ownership. These stated that aid should be aligned to nationally agreed development priorities while a new vertical fund would direct aid funds only to trade priorities.

In early 2006, the WTO began working on a comprehensive inventory to inform the work of the Task Force by inviting the OECD to provide data on bilateral AfT flows. WTO asked the OECD to contribute to the global monitoring effort, in particular to examine: $i$ ) how much aid do donors provide in support of trade; ii) how effective are these programmes; and, iii) how to make AfT an effective tool for helping developing countries, particularly LDCs, to fully benefit from trade liberalisation and WTO agreements (OECD, 2006a). These questions have defined the WTO-OECD monitoring work ever since. The subsequent OECD note promoted the use of the OECD DAC Creditor Reporting System to assess AfT commitments. The OECD noted that a consensual and realistic definition of Aid for Trade was needed. It also acknowledged that there were trade-offs between 'the scope of the agenda, the scaling up of aid commitments, and managing these commitments to deliver results' (OECD 2006b:21). This was particularly important 'given the likelihood that WTO negotiators request a highly credible mechanism to ensure that commitments are forthcoming and the potential demands to even further widen the scope of aid for trade to also include adjustment costs' (OECD 2006b:22).

The approach set out in the OECD report on Aid for Trade: Making it Effective (OECD, 2006a), provided the parameters of the official monitoring effort. This suggested that AfT should be guided by the Paris Principles of Aid Effectiveness, which committed countries and organisations to continue to increase efforts in harmonisation, alignment and managing aid for results with a set of monitorable actions and indicators. The definition of AfT itself was based on the Paris Principles, in particular country ownership and alignment with developing country strategies. Projects and programmes would be considered as AfT if these activities have been identified as traderelated development priorities in the recipient country's national development strategies (WTO, 2006b). Such definitions enable partner countries to tailor AfT to their national conditions and needs and enable better management of the programmes. At the same time, clear benchmarks are necessary for reliable global monitoring of AfT flows. This is rather difficult for AfT given that it is an expanding agenda. Nevertheless the benchmarks below were selected for measuring flows and assessing additionality. This included ODA for:

arguably the more important need. Page (2005) suggested that a Preference Erosion Compensation Fund be created and Prowse (2006) called for Increasing Support for Trade Adjustment and Integration. 
- $\quad$ Technical assistance for trade policy and regulations: for example, helping countries to develop trade strategies, negotiate trade agreements and implement their outcomes;

- $\quad$ Trade-related infrastructure: for example, building roads, ports and telecommunications networks to connect domestic markets to the global economy;

- $\quad$ Productive capacity building (including trade development): for example, supporting the private sector to exploit its comparative advantages and diversify its exports;

- Trade-related adjustment: helping developing countries with the costs associated with trade liberalisation, such as tariff reductions, preference erosion, or declining terms of trade; and,

- $\quad$ Other trade-related needs: if identified as trade-related development priorities in partner countries' national development strategies (OECD/WTO, 2009:52).

The Aid for Trade Initiative has inspired considerable debate in the academic and policy community. Page (2007) stated that the Initiative was 'revolutionary in the acceptance by international consensus of a role for the WTO in aid and of the limitations of trade' (Page, 2007:3). Laird (2007) noted the concerns and suspicions of some developing countries about the emerging Initiative given the 'long list of unanswered questions, and some bad experiences of recent trade reforms', developing countries regarded 'aid for trade more as Kool-Aid, rather than cool aid!' (Laird, 2007: 2). Langan and Scott (2011) questioned the development credentials of AfT given the patterns of disbursements to middle-income states. Hoekman and Wilson (2010) question whether the Initiative sufficiently raised awareness in the broader development community of what the AfT Initiative entails and how it works. Prowse argued that aid to compensate for preference erosion lacked the level of innovation and financial support needed (Prowse, 2010). While a number of authors have criticized the global effort for the limited data and analysis on the impact of Aid for Trade on the ground, Adhikari (2011), Cadot, Fernandes, Gourdon, and Mattoo (2011). Basnett et al (2012) in a comprehensive overview offer a generally positive assessment of the Initiative but also highlight the need for a greater understanding of 'when and under what circumstance Aid for Trade works best' (Basnett et al, 2012: 2). The rest of this article will offer a comprehensive assessment of the Initiative in terms of governance and developmental utility.

\section{Contextualising the AfT Initiative: international aid governance}

The general context for international development co-operation is related to broader challenges of 'global governance'. The core fact here is that in the absence of any central authority we have a heterogeneous set of international arrangements or 'regimes' (institutions, laws and norms) in specific sectors of the international system (Hasenclever et al., 1997, Young 1999). The various forms (regimes) of co-operation vary widely in 
terms of the specificity of rules and norms and the degree of institutionalisation. A limited number of sectors, such as international trade, are strongly legalised (for obvious reasons) while international development policy co-operation relies much more on soft methods. There is a substantial body of literature, in political science, public administration and cognate fields, that explains how these soft methods can work: that is how norms, ideas and policies can spread internationally without an overarching implementing authority (Risse, Ropp and Sikkink, 1999; Finnemore and Sikkink, 1999; Checkel, 2001; Pagani, 2002). This rests on an essentially liberal worldview, based on sociological/cultural (Finnemore, 1996) and/or rationalist argumentation (Axelrod, 1997; Haas, 1989). The basic premise is that norms and ideas can be internalised by international elites through processes of socialisation, mutual learning and peer pressure. Naturally the quality of the ideas and the credibility of research behind them are also crucial. Bearing this in mind, to be effective an international regime would have to facilitate regular interaction and dialogue (as well as possessing a powerful rationale for the ideas/norms/policies in question). It would then institute various forms of peer pressure - through monitoring and reporting procedures - hoping to capitalise on the image consciousness of the stakeholders (as well as the internalisation of the ideas involved) to secure compliance.

The international development 'regime' is densely packed with institutions of different types: including state donors, regional/international/mulitilateral organisations and non-governmental organisations of different types. ${ }^{3}$ There is no one hegemonic international organisation. The UN's near universal membership gives it unique legitimacy and its constituent agencies and organisations have played a leading role in promoting co-operation at all levels. At the highest political level, the Millennium Development Goals outlined agreed objectives for all development stakeholders up until 2015. There are also UN-led efforts to rally financing more generally. As discussed below, specific agencies such as UNIDO have made substantial contributions to the effort to track and monitor AfT flows. Of course the World Bank has also played a major role in setting the intellectual and research agenda in development policy in general. The DAC has played a leading role in setting standards for developed state donors. More generally it has set the statistical norm for classifying and measuring aid flows. It also serves as a forum for the exchange of ideas on best practice and its role in evaluation is particularly important in encouraging mutual learning. In recent years increased aid has been given by "non-traditional donors' from the emerging world, China in particular (Manning, 2006; Paulo and Reisen, 2010; Chandy and Karas, 2011; Lightfoot and Kim, 2011). These have a role in the governance of the international development community through participating in the (DAC-led) Working Party on High Level Effectiveness. The aforementioned Paris Declaration on Aid Effectiveness of 2005 (at the $2^{\text {nd }}$ High Level Forum on Aid Effectiveness) was a landmark agreement to harmonise aid management procedures and adhere to standards of transparency and ownership. The Busan conference of 2011 (the $4^{\text {th }}$ Forum) attempted to extend these 'Western'/ DAC development aid norms to emerging donors. While emerging donors signed up to Busan on the principle of shared goals but differentiated responsibilities, neither China nor India participated and Brazil remained non-

\footnotetext{
${ }^{3}$ See Rogerson and Killen (2010) for an outline of the contemporary international aid architecture.
} 
committal at the first Ministerial of the Global Partnership for Effective Development Co-operation in April 2014.

The impact of these initiatives has been mixed. Concerning the goals of the Paris Declaration, official and academic studies have shown that implementation has been limited (OECD, 2011a; Chandy and Kharas, 2011). Developing countries still get 'too little aid from too few donors' (OECD, 2011b: 4). There are numerous explanations for these disappointments. Firstly, foreign aid may be used to support economic or geopolitical and security interests (Schraeder et al. 1998; Holden, 2009: 20-22), which will inevitably affect co-operation. Apart from considerations of self-interest, donors may have genuinely different opinions in regard to development strategies, which could lead to a divergence from global development priorities or partner government needs. Furthermore, even assuming 100\% commitment from the political leadership and upper administrative echelons translating policy into reality is always a major challenge. Note the extensive literature on the policyimplementation gap (Schofield, 2001). On a systemic level, the sheer complexity of the international aid architecture and the vast number of aid relationships (OECD 2011b: 4), impose acute limitations. When it comes to 'emerging' donors such as China, much skepticism has been expressed as to the likelihood of them aligning themselves with substantial 'mainstream' aid community practices and goals (Woods, 2008). This would be one of the challenges of the AfT Initiative. There are more positive stories to tell and the 'aim for the sky and reach for the trees' aphorism has some resonance here. For example, although commitments on financing are rarely met in their entirety, studies do argue that this form of target setting has helped increase overall levels of ODA (Kharas, 2010). Kharas notes that aid flows increased by 35 percent in real terms from 2004 to 2010, a fact which he attributes to the Gleneagles G8 Summit commitments of 200). He also notes that countries that promise more deliver more (even if they do not achieve their targets). In the UK, for example, the existence of an international target helped to bolster the coalition government's decision to ring-fence the aid budget, in an era of drastic expenditure cuts. Also the priorities embedded in the MDGs and in the new paradigms of poverty reduction and human development have percolated through the different aid agencies, to a greater or lesser degree.

In summary, none of the various forms of co-operation regimes has overcome the problems created by state donor autonomy, the asymmetries between developing and developed countries, and the sheer heterogeneity of the system. However, international development co-operation efforts can 'work' in terms of securing increased funding and in changing policies, to an extent. What are the implications of this for the AfT agenda? The idiosyncrasies of national aid donors encouraged some to argue that a multilateral instrument should be set up to distribute AfT (Charlton \& Stiglitz; 2006). Such a fund would still depend on finance and co-operation from states and so the general points about international co-operation would still apply. Also the institutional landscape of aid is already over-populated and adding further to its complexity would have its downsides. Clearly, the 'AfT regime' would face similar challenges to other international aid initiatives. As noted earlier, collating statistics here is particularly challenging. The AfT agenda's call for a focus on LDCs was also likely to 
be challenging as a large proportion of gross ODA goes to non-LDCs (OECD/WTO, 2013), and middle income countries are more attractive partners for infrastructural and productive capacity assistance. Furthermore they have much greater absorption capacity for AfT. The Task Force explicitly linked the AfT agenda to the Paris Declaration and other international agreements. However there may be issues of coherence in practice. For example, the AfT agenda implied a greater focus on export-led growth than the poverty reduction paradigm which had dominated development aid policy. More generally, there is a tension between the tendency to get donor commitments on spending on certain issue areas and country ownership of development aid. A related potential tension exists between the multilateral and regional conception of AfT (which considers its global and regional benefits) and the goal of national country ownership. Unless the former conception of AfT is extremely strongly formulated and supported, national ownership would have to be the primary norm. At the ideational level, there is the potential for the AfT Initiative and process, to serve as a transmission belt for a new paradigm of trade and development, although the agreed agenda may well be too broad to serve as a meaningful framework for this. The positive side of its broad approach is that it was more politically feasible to all sides and any aid coordination effort has to gain the support of the major state donors and developing countries or it will become irrelevant. The paper now turns to how the agenda has been implemented.

\section{The Aid for Trade Agenda in Practice: Adapting and refining the monitoring mechanism}

Once the agenda had been established, the task of the WTO and OECD was to monitor Aid for Trade - to hold stakeholders to account - and to facilitate dialogue on this form of aid. The most salient element of the monitoring process is the biannual Global Review. The monitoring is based on a spotlight, not a microscope: it provides general impressions and allows progress to be assessed at the global level. There was no way for the international institutions to compel donors to live up to their commitments but the objective of monitoring was to create incentives through enhanced transparency, scrutiny and dialogue. More substantially it was to foster synergies between trade and other economic policy areas in developing countries and improve the coherence of AfT with overall donor strategies.

The original focus was on the measurement of flows, raising awareness about the role of trade in development and creating a community of best practice. It has subsequently evolved to examine implementation, effectiveness and results. In 2007 it was decided to use the OECD-DAC Creditor Reporting System (CRS) for the collection and monitoring of the broader AfT agenda instead of the Trade Capacity Building Database (TCBDB). The categories of AfT used for the purpose of tracking flows are often taken as the working definition of Aid for Trade. Consequently, many commentators have made the case that the 'definition' is too broad and this diminishes its effectiveness (Adhikari, 2011 and Hallaert, 2013). However, developing countries wanted these broader forms of aid. The objective of monitoring flows was to assess additionality and to hold donors who made pledges at the Hong Kong Ministerial to account. The starting point for this discussion was that it was impossible to define a priori what constituted Aid for Trade e.g. a component of an infrastructure project may be trade- 
related but it may also have other objectives. ${ }^{4}$ Therefore a set of broad proxies in the CRS were selected corresponding to the categories listed above. Furthermore, members of the OECD Working Party on Statistics agreed to modify the CRS to accommodate the collection of AfT data by adding a trade-related adjustment code and a policy marker for trade development activities. ${ }^{5}$

While this statistical system is imperfect, new data collection would have been a significant and costly undertaking and would have raised comparability issues over time and between donor agencies. Transparency is only worthwhile if the data is credible and the CRS is an accepted source of aid data. But critics argue that the proxies overstate the 'true' amount of AfT. Aid for trade policy and regulations is clearly trade-related and the trade development marker helps identify building productive capacity projects with a trade objective, but the infrastructure proxy has come under particular scrutiny. The World Bank suggested that it might be possible for donors to more specifically identify the proportion of infrastructure projects that have a trade objective. However it would be difficult to standardise such an approach across donors as estimating the trade component among competing objectives is somewhat arbitrary. For such a new measurement to work there would first have to be extensive negotiations to clarify a precise acceptable methodology. It would also have required substantial resources to monitor it. The opportunities for donors to inflate figures either due to a genuine difference of opinion or the various forms of institutional self-interest (discussed in the last section), would be enormous. While there are limitations with the existing approach, the full set of proxies allows for transparency and partners are in a position to more tightly define Aid for Trade in their national dialogue with donors. At the global level, the proxies help assess donor accountability.

There were few other competing ideas for monitoring flows generated in the Task Force. One member suggested that the WTO Secretariat consider establishing a webpage on the WTO website as a platform for information release and exchange. A notification mechanism in the WTO was also suggested, with country-specific demands for AfT, donor response and details of how programmes were proceeding and what benefits the recipient country have drawn from the programme. A register for Aid for Trade facilitation was again discussed as part of the Trade Facilitation negotiations at the WTO. However this was outweighed by the importance of using an existing and credible system to track donor commitments so as not to duplicate effort or to generate information that would not be comparable over time and between countries, verifiable or satisfy donor accountability (As

\footnotetext{
${ }^{4}$ The LDC submission to the WTO Task Force expressed reservations about this practice, i.e. "'ECD does not distinguish between what could be narrowly defined as a trade-related infrastructure from more general multi-purpose infrastructures. Under that practice, figures for infrastructure seem to be exaggerated' (Zambian Government, 2006). However it would be extremely difficult to identify specifically the trade-related component in every project.

${ }^{5}$ OECD aid-for-trade statistics come from the Creditor Reporting System (CRS). Established in 1967 by the OECD DAC, this database collects information on activities related to ODA and other official flows (OOF) going to developing countries. The CRS is based on reporting directives approved by the OECD DAC and is based on reporting from the member countries of the OECD DAC, multilateral institutions and a number of non-DAC donors. The OECD DAC collects, collates, and verifies the consistency of the data, and maintains the database. The CRS does not measure South-South partnerships. However, steps have been taken to capture certain elements of South-South flows through self-assessments. The CRS has become the internationally recognised source of data on the geographical and sectoral distribution of aid.
} 
noted previously this is vital for an effective peer pressure mechanism). The Task Force Recommendations stated that Multilateral and regional actors should be encouraged to report regularly on their Aid for Trade activities, progress and impact. Furthermore it recommended that an assessment of Aid for Trade - either as a donor or as a recipient - should be included in the WTO Trade Policy Reviews/TPRs. A WTO case story in 2011 provided details on this, based on pilot exercises, after which the WTO pointed to additional internal coordination issues in middle income developing countries and LDCs.

The increased profile of AfT would inspire a range of existing technical assistance and capacity building efforts and illuminated various informational and implementation gaps. A number of international organisations have responded to this. Within the UN system, the Inter-Agency Cluster on Trade and Productive Capacity has long provided assistance in building the capacity in the area, in particular in supply side capacity; export capacity; capacity to implement trade and trade-related rules; dispute settlement capacity; negotiating capacity; as well as in research and analysis (UN, 2012). UNIDO through its comprehensive Trade Capacity Building Resource Guide has provided transparency, practical information on the services available and useful contacts. Since the Guide was launched in 2008, its coverage has expanded beyond the UN system to include the activities of multilateral and bilateral donors. Such initiatives have helped to co-ordinate country-level technical assistance and programming and implementation activities (UNIDO, 2010, 2013). Clearly, information and knowledge exchange are essential in realising the objectives of the Initiative. ${ }^{6}$

\subsection{The Global Reviews}

The Global Reviews have been the major institutional forum of the AfT initiative. They offered the opportunity for a wide range of actors (including high-level decision-makers) to meet, they provided a focal point for analytical and research work; and they were the most high-profile events As such they were the primary means of facilitating dialogue and diffusing best practice, although, as ever the success of the Reviews would be contingent on the participation of the donors and developing countries. The task of the WTO/OECD has been to provide credible data, stimulate participation by a wide range of actors, facilitate dialogue and rally funding. The Reviews also provide landmarks for us to trace the development of the AfT initiative, as it expanded in terms of thematic scope and participation.

The first monitoring exercise in 2007 was based on a three tier monitoring framework (global ODA flows, donors' self-assessments and partner country self-assessments). The Aid for Trade questionnaire was selected as a tool to elicit qualitative information. In the first round of questionnaires, the engagement by DAC donors and multilateral institutions was strong. Donors provided comprehensive self-assessments of their strategy, pledges and funding, implementation, and participation in mutual accountability arrangements. The response from non-

\footnotetext{
${ }^{6}$ The UNDP proposed establishing a Knowledge Network for Aid for Trade in 2010, but donors balked at the more than USD 1 million running costs and decided instead to use existing knowledge sharing platforms. The World Bank also proposed on various occasions an independent evaluation body to contribute to the public good of aid-for-trade evaluations. This has not been set up to date. The OECD Development Assistance Committee Network on Development Evaluations hosts a database (DeREC) which contains various evaluations submitted by members and includes those relevant to trade.
} 
DAC donors to the donor questionnaire was encouraging (five responses) but neither China nor India (both members of the Task Force) took part. It was suggested that a specific questionnaire on South-South Cooperation might improve reporting from emerging economies.

It was envisaged that responding to the questionnaire would facilitate national planning of trade and development programmes in developing countries, provide partners the opportunity to communicate to the international community and enable the dissemination of best practice. However, the response rate from partner countries was very low and only 8 partner countries responded. It thus became essential for the monitoring mechanism to improve the participation of partner countries. The OECD and WTO took several steps to communicate these benefits and also increased the relevance of the questionnaire (OECD, 2008a). The donor questionnaires did reveal that AfT was increasingly prioritized in donors and partner countries' plans. Moreover, the development of new strategic statements, a gamut of initiatives to strengthen in-house capacities and increased prioritization in donor-partner dialogues indicated that AfT was likely to attract additional resources in the coming years (OECD, 2008b). The 2007 report also presented the AfT data for a baseline period of AfT proxies for an average of the years 2002-05. Progress in donor commitments was assessed based on this baseline. ${ }^{7}$

The Second Global Review (2009) took place in the midst of the Great Recession, it sought to strengthen the engagement of partner countries and regional organisations (reflecting the importance of tackling regional constraints to trade). Furthermore, the 2009 report started tracking progress in implementation, requiring more detailed disbursement data. In terms of aid delivery, progress on trade mainstreaming and performance were assessed. There was a focus on promoting greater mutual accountability which required broadening the monitoring framework to expand the range of stakeholders, i.e. partner countries, regional organisations and non-DAC donors. The objective of a specific questionnaire on South-South co-operation helped to elicit more information about South-South practices and programmes, as well as the thinking that lies behind them. Argentina, Brazil, Chile and China - countries which have long played an important role in development cooperation responded to this questionnaire. In addition India responded but after the deadline and so they were not included in the analysis. A new section dedicated to elicit information on how donor and partner countries were addressing regional challenges was added to donor and partner questionnaires. Binding regional constraints, such as poor cross-border infrastructure, were clearly acknowledged. The particular challenges of working at the regional level were highlighted such as insufficient regional co-operation and concerns about asymmetric costs and benefits. The Regional Development Banks were seen as the natural partners for addressing these and other regional challenges.

\footnotetext{
${ }^{7}$ A commitment is a firm written obligation by a government or official agency, backed by the appropriation or availability of the necessary funds, to provide resources of a specified amount under specified financial terms and conditions and for specified purposes. A disbursement is the release of funds to or the purchase of goods or services for a recipient; by extension, the amount thus spent.
} 
The focus of the Third Global Review was on drawing lessons about impact on the ground and surveying how best to maximize the potential of Aid for Trade. The 2011 survey invited partner countries, donors and providers of South-South co-operation to explain how they measured results in AfT programmes and projects, metrics for success and what kind of policy environment is conducive to successful outcomes. For the first time, regional economic communities/RECs also provided their assessment of AfT. For this review, case stories provided an important source of additional information. Case stories were well suited to offer a large group of stakeholders an opportunity to share experiences about what is working (or not) at the national and regional level. In total, 274 case stories were received from more than 150 countries covering all major developing regions and income categories. Bilateral donors and UN organisations were also large contributors, although some of the multilateral development banks were under-represented. On the basis of these case stories, regional analyses were prepared by the WTO and OECD secretariats in collaboration with regional development banks and regional economic commissions. ${ }^{8}$ Hallaert has vigorously criticised the review process in general and the case stories approach in particular (Hallaert, 2013). Case stories and questionnaires may, he argues, be filtered through 'rose-tinted glasses'. On the other hand these views do not have to be accepted uncritically, and this method can help move monitoring beyond a technocratic activity to a real exchange of views.

The Fourth Global Review was characterized by the attempts to connect AfT to the broader trade agenda by examining value chains and expand the partnership by better engaging the private sector. Over 700 firms responded while the input of partner countries, donor agencies and providers of South-south co-operation remained strong. Discussions highlighted the constraints inhibiting firms in developing countries from connecting to value chains. These included access to finance, the thickness of borders, inadequate infrastructure and poor business environments. AfT has a role to play in fostering public-private co-operation to address market failures and overcome these barriers (OECD/WTO, 2013). WTO members welcomed the focus on value chains, and the active involvement of the private sector in the Review. The broader agenda, however, risks diluting the focus of the monitoring approach. Also, the profit motive of the private sector is still viewed with some suspicion and the type of engagement envisaged in public-private co-operation remains somewhat vague. Others argue that the implications of Global Value Chains for development have been interpreted in an overly simplistic way by institutions such as the WTO (Ravenhill, 2014). Furthermore there is still no consensus on the fundamental definition and focus of AfT. Hallaert (2013) and others have argued that the Reviews should focus on trade facilitation and a narrow range of trade policy and regulation issues. (Recent trade agreements provide this opportunity, see below).

It is uncertain how high a priority AfT will be for the new WTO Director-General Roberto Azevedo but the Review process is scheduled to continue. The WTO Bali Ministerial concluded with a landmark Trade Facilitation Agreement (TFA) - the first multilateral trade agreement successfully negotiated in 18 years and the

\footnotetext{
${ }^{8}$ These analyses included three reports with a regional dimension: Asia-Pacific Case Stories: A Snapshot of Aid for Trade on the Ground; Latin American and Caribbean Case Stories: A Snapshot of Aid for Trade on the Ground; and African Case Stories: A Snapshot of Aid for Trade on the Ground in Africa.
} 
first such accord concluded by the WTO (Neufeld, 2014). While India temporarily withdrew support because of unrelated concerns about the food security, implementation is now proceeding. An unprecedented aspect of the Agreement is that it requires developing countries to implement only if sufficient funds are provided by donors. WTO members resisted creating a separate reporting mechanism and agreed that OECD members would use their CRS reporting on trade facilitation to assure developing countries that assistance would be provided to help them implement the provisions of the agreement. As such the Bali TFA fits into the broader AfT initiative (while its focus is much narrower). To promote the role that AfT can play in supporting trade facilitation, the theme "reducing trade costs" has been selected for the Fifth Global Review of Aid for Trade, planned for mid-2015.

If one accepts that the main objective of the Reviews is political rather than technical - to profile what is happening and promote actions from all stakeholders - the process can be considered a qualified success. The Global Reviews have led to active engagement, improved statistics and the interchange of ideas. Of course, broader debates as to the definition and results of AfT have never ended and the Global Reviews have been criticised for failing to address these issues head on (Basnett, 2011). Realistically, such a process (which had to be decentralised and flexible) could not be expected to resolve definitively these issues. Bryers, (2013) commented that Reviews remain 'very donor-oriented'. Arguably, this was inevitable, given that a central objective was to rally finance, but participation from the Global south did increase.

\section{Achievements and limitations of the Initiative?}

The principal objective of the Initiative was to mobilize aid resources. While it is difficult to conceive a counterfactual about the evolution of flows in the absence of the Initiative, evidence suggests that this objective has been achieved. Even Hallaert (2013) accepts this point. It is worth revisiting the expectations about flows. OECD (2006) ran projections on different scenarios, including a doubling of AfT flows from DAC members. Assessing these projections with the latest data available (deflated to 2004 US dollars) indicates that the Initiative has exceeded expectations and resources have more than doubled (Figure 1). 
Figure 1: DAC Members' net ODA 1995 - 2005 and DAC Secretariat simulations of net ODA to 2006 and 2010

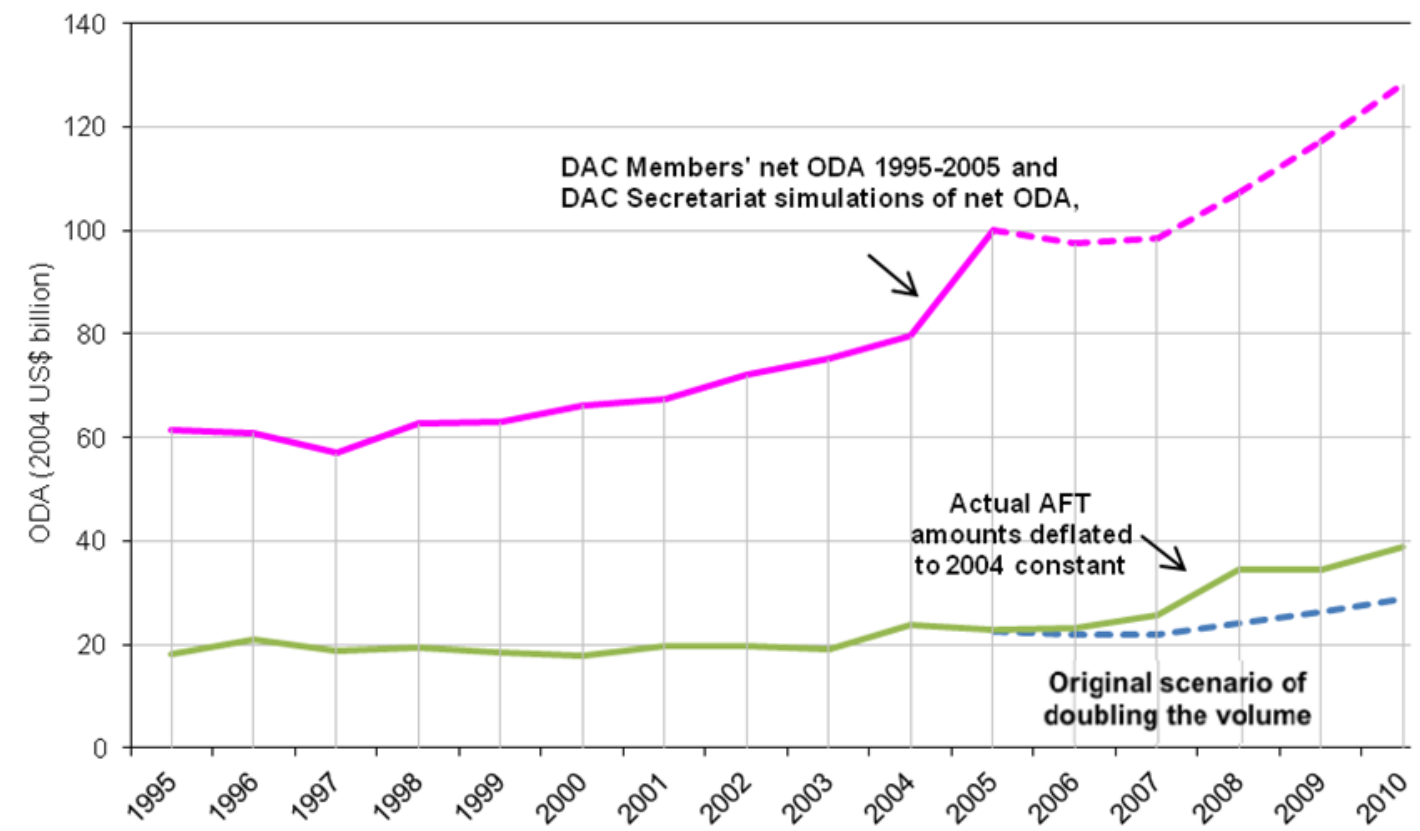

Source: OECD Creditor Reporting System

During the Task Force discussions, it was clear that without clear evidence of extra ODA to spend on trade, developing countries would feel that 'the whole exercise is academic' (WTO 2006d). While the Initiative has helped to mobilise resources, a question remains about whether these flows have been additional. Stiglitz and Charlton (2012) assert that they have not. A useful way of measuring this is to look at the share of AfT in overall ODA. The data in Figure 2 indicate that on average the share remained more or less the same at $33 \%$ between 2002 and 2010. A stable share indicates that the decades-long fall in aid to the economic sectors has been checked and that the increased resources did not come at the expense of other sectors such as health or education. So on this central criterion - the Initiative succeeded. However in 2011 and 2012, with a general downturn in ODA, the share of AfT in overall ODA increased strongly to almost $40 \%$, which may well be at the expense of the social sectors.

Despite the many failures of donors to meet their pledges on for example the Gleneagles commitment, according to the Aid for Trade at a Glance 2009 (OECD, 2009), the Hong Kong pledges made by the European Union, Japan and the United States have been met. This achievement is all the more striking given that some donors including the United States had said that additional AfT was conditional on a good result in the Doha 
negotiations (WTO, 2006c) ${ }^{9}$. Though these pledges were met, they were made before a definition existed and the broad definition perhaps made it easier for donors to deliver.

Figure 2: Aid for Trade as a proportion of Total Sector Allocable ODA (\%)

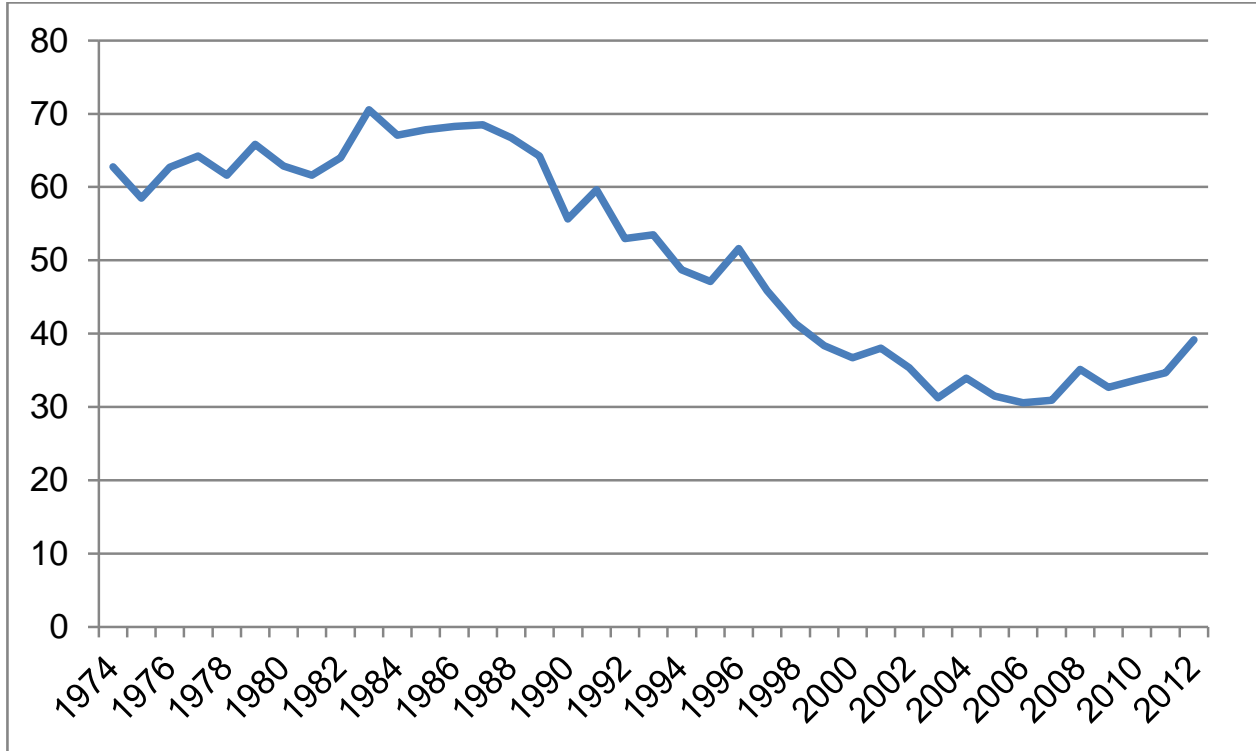

Source: OECD Creditor Reporting System

While the original pledges have now expired - in 2010, the assembled leaders of the Group of Twenty (G20) pledged to (at least) maintain AfT levels that reflect the average of 2006 to 2008 beyond 2011. The G20 tasked the OECD and the WTO to monitor progress and subsequent reports for the French and Russian Presidencies indicated that Members of the G20 Development Working Group that report their aid to the OECD have met their pledge to maintain AfT flows. Only the United States among the major donors failed to register an increase. The G20 provide the bulk of AfT with commitments of USD 34 billion in 2012 (over $60 \%$ of total support), 44\% higher than the 2006-08 baseline (OECD, 2014). Pascal Lamy described the G20 pledge as an insurance policy for the Initiative. The pledge is not particularly strong, this is basic insurance coverage at best, but it has been met.

Notwithstanding these achievements Aid for Trade has been affected by the budgetary constraints faced by donors in an era of economic crisis. This is a challenge facing overall development assistance and in 2011 and

\footnotetext{
${ }^{9}$ In Hong Kong, Japan pledged $\$ 10$ billion for building trade-related infrastructure. United States Trade Representative Robert Portman announced that the U.S. would double its annual aid-for-trade spending from \$1.35 billion in 2005 to \$2.7 billion in 2010. Peter Mandelson on behalf of the European Union pledged that spending by the Commission and by the combined members states on trade-related assistance would each rise to Euros 2 billion a year by 2010(WTO, 2006c).
} 
2012, ODA from DAC members fell for the first time (excluding debt relief) since 1997. Aid for Trade flows declined in 2011 but recovered strongly in 2012. However, the positive aggregate figures were undermined somewhat by the continued decline in AfT flows to the Least Developed Countries. In addition, the terms of assistance hardened with two thirds of Aid for Trade provided in the form of loans, up markedly from the even split between grants and loans in previous years. Aid for trade has been particularly affected by a DAC decision to accept the recording of loans from the European Union, Germany and France which had been questioned on the grounds that they failed to meet the conditions of concessionality in character. ${ }^{10}$ The latest figures on aid untying also suggest some slippage in DAC donor commitments to untie aid. So while the quantity of aid continues to expand (OECD, 2014); the quality and distribution seem to be affected. This will be a major test of the Aid for Trade Initiative, to see if the spotlight effect can put pressure on donors to reverse these negative trends.

\subsection{Use of Existing Systems}

The global monitoring has been delivered by two small teams in the WTO and the OECD co-ordinating an effort where the majority of the inputs are provided by member governments and other international organisations. No new multilateral fund or monitoring mechanism was created, and thus the AfT Initiative has not added to the, already overcrowded, set of donor organisations. In their critique of the Initiative Stiglitz and Charlton (2012) have suggested, again, establishing an Aid for Trade fund, this time managed by UNCTAD. Yet such instruments can have their own pitfalls. Although it cannot be directly compared with the AfT Initiative, as it is much smaller and more specifically targeted, the experience of the Enhanced Integrated Framework ${ }^{11}$ is salutary. It has struggled to raise finance: in 2007 at the High-Level Conference in Stockholm pledges were made of up to US $\$ 170$ million, against a target of US\$250 million. Also a fund alone cannot promote the changes that the Global Review mechanism has and such funds often fail to connect to the broader development agenda. Furthermore such instruments may sit uneasily with country owned strategies and priorities. ${ }^{12}$

The use of existing systems rather than a specifically created register or database has enabled the international community to quickly assess progress against an established baseline. A new instrument would have lacked baseline information, and would have taken years to gather sufficient data to make meaningful conclusions about donor accountability. Indeed the Bali Agreement on Trade Facilitation underscored the importance of using existing accountability and transparency systems. The lesson of AfT suggests that pledges are best assessed using existing reporting and monitoring mechanisms. The examples above suggest that there may be more precise ways to monitor Aid for Trade, but with substantial costs in terms of cost, timing and burden on reporting

\footnotetext{
${ }^{10}$ More information on this issue can be found in Hynes and Scott (2013) and at the OECD webpage on development finance: http://www.oecd.org/dac/financing-development.htm

${ }^{11}$ The EIF is about building superstructure: capacity to integrate trade policy into national development strategies; building capacity to implement WTO Agreements. This includes certain supply-side constraints.

12 The EIF has a difficult task in focusing on Least Developed Countries. It is a matter of debate whether trade should be a top development priority given the other economic and social challenges facing LDCs. In addition fragile states may not have the conditions to foster trade and so there are risks that building trade capacities will not lead to sustained increase in trade.
} 
agencies. The Initiative is guided by the Paris Principles and represents a clear example of these principles in action. Properly applied, they lead to mutual accountability with a shared agenda with clear objectives and reciprocal commitments. Incentives are created for this through monitoring and evaluation of these commitments with dialogue and review. Through its emphasis on a global-light, country-heavy monitoring mechanism the AfT experience offers lessons for the monitoring framework which is being pursued through the Global Partnership for Effective Development Co-operation.

\subsection{Partner engagement}

The Monitoring process in this period largely achieved its institutional objectives - this should not be underestimated. Its credibility has been enhanced by meaningful engagement from a number of different partners, as can be seen in Table 1. Engagement has been impressive and the number of elements in the framework has expanded without undermining the quality of the monitoring. The OECD/WTO questionnaire on AfT, though based on self-assessment has proven useful. The questionnaires of 2009, 2011 and 2013 were increasingly detailed and probed more extensively a range of AfT issues. The survey is now well established and has proved to be an essential tool in gathering information on objectives, strategies, plans, implementation and emerging results. It also provides details of how donors, providers of south-south co-operation and regional economic communities are responding to an evolving trade and development environment. However some respondents indicated that two years is too short a period in which to generate new evaluation findings, or to assess strategic or programming changes.

Table 1: Stakeholder engagement in OECD/WTO monitoring

\begin{tabular}{|l|l|l|l|}
\hline & 2007 & 2009 & 2011 \\
Donor Questionnaire Responses & 39 & 57 & 43 \\
Partner-country Questionnaire Responses & 8 & 89 & 84 \\
South-South Questionnaire Responses & & 5 & 10 \\
Regional Economic Communities & & & 9 \\
Case Stories & & & 274 \\
\hline
\end{tabular}

Source: OECD/DAC records. ${ }^{13}$

The 2011 Aid for Trade Questionnaire solicited the views of donors on the usefulness of monitoring at the Global Level. Donors almost universally responded positively to the Initiative, indicating that it had raised the profile of trade and awareness about the cross-cutting nature of trade. It also generated momentum at the global level and re-enforced the efforts on the ground. However the comments of many members reflected some unease about several dimensions mostly related to definitional issues and the scope of AfT (which makes it a challenge for donors and partners to understand it) as well as reliance on 'subjective assessments', questions of attribution

\footnotetext{
${ }^{13}$ The reason for the apparent reduction in 'donor responses' in 2011 is that in in 2009 countries such as Argentina, Brazil, China... and some regional organisations filled out 'donor questionnaires' whereas in 2011 they were filed under other categories.
} 
and the contribution of the Global Review process and the role of global level work given that most of what matters in AfT happens at the country level.

Considerable support was given to the idea of developing indicators that would help provide a sense of the progress and challenges at country level. The OECD is currently developing a menu of indicators for trade. ${ }^{14}$ Implicit support came from the United States, while acknowledging that trade is an umbrella that covers many sectors and success can involve many variables, it is difficult to monitor results in this area. 'Our discussions have focused on sharing lessons learned and best practices, which we think is the most productive approach'. This is also the approach taken by the overall monitoring. In something of a surprise, the European Union, which is a big supporter of the global monitoring, answered 'not sure' on the value of the global monitoring while also noting that 'the EU attaches great importance to monitoring of its aid for trade. It sees value in exchanging experiences among partner countries and other donors in this regard, and also in working together to define and extend the use of objectively verifiable indicators for results and impacts'. However the EU did not think that 'global aid for trade monitoring should seek to establish global priorities for aid for trade, as challenges to countries trade expansion are very country specific'. The statement is somewhat ambiguous but indicates some misgivings. ${ }^{15}$

The vast majority of developing countries also endorsed the global monitoring. Only six developing countries had a negative assessment of global monitoring. In some cases this negative perception stems from the failure to realize higher AfT flows. For example Jamaica stated that 'the process has not resulted in increased volume of aid for trade' while Mauritius urged Developed countries 'to implement the pledges they made on aid for trade'. This was also the case for Saint Lucia which highlighted the challenges of accessing funds, the need for greater awareness and the 'conditionalities applied to accessing these facilities'. Zambia positively assessed the Initiative but made the point that "the global monitoring system is very dependent on national monitoring systems". A problem highlighted by Zambia as well as others is that "national systems are weak and not properly developed, thus acting as a hinderance to accurate monitoring at both national and global levels. There is therefore, a need to, where they exist, strengthen and where they do not, establish good National monitoring systems'. Lao PDR noted that it continued to be 'a challenge to align donor funds with national priorities'. The Gambia noted that 'a major challenge is the coordination and monitoring at the national level. Currently, traderelated assistance is fragmented into different sectors and there is no central body for coordination'. Providers of south-south trade-related co-operation were most positive about global monitoring. China underscored the concerns some developing countries had about AfT funds. China stated that AfT needed to be improved and that

\footnotetext{
${ }^{14}$ Early evaluations of aid-for-trade programmes highlighted a lack of explicit targets in many projects and consequently a lack of effective monitoring. To be useful, targets need to be decided beforehand, be measurable ex ante and ex post, agreed upon by all actors (OECD 2006a, 2011c).

${ }^{15}$ Aid for Trade Donor and Partner Questionnaire Responses can be found here: http://www.oecd.org/aidfortrade/selfassessments.htm
} 
developed countries should increase their aid efforts and honour their commitments. Not surprisingly China also emphasised the need to improve infrastructure investment 'especially in regional traffic arteries' and to 'help partner countries to build their trade capacity and improve their strategic trade planning'. India mentioned the need to improve the identification of AfT projects. In 2014 an independent evaluation of the OECD's role in monitoring reported a high degree of satisfaction of developing partners with its work; officials surveyed gave it an average score of 4.3 out of 5 (Saana Consulting, 2014: 11).

\subsection{Mobilising national and regional programmes}

The global Initiative has catalysed efforts for raising awareness, mobilizing funds and aiding project implementation and co-ordination in almost every region. The Regional Development Banks held a set of regional reviews in 2007 and have followed up in various ways. The Asian Development Bank established a regional technical group on Aid for Trade. The Inter-American Development Bank established an Aid for Trade fund, a multi-donor thematic fund which provides grant resources to support AfT implementation in Latin America and the Caribbean. The AfDB, working with the UNECA, has conducted various reviews and undertaken monitoring work in Africa. The AfDB also established an Aid for Trade Fund (African Development Bank/AfDB, 2012 ${ }^{16}$ ) and more recently the Islamic Development Bank in collaboration with ITC, UNDP and ILO launched an Aid for Trade Initiative for Arab States (IsDB, 2012 ${ }^{17}$ ). UNECE has mobilised support for AfT in Central Asia where the EBRD are also active through the SPECA Initiative. Regional integration in many developing areas has been highly politicised. This has led to overlapping membership, especially in Africa (with attendant problems), and a flurry of ambitious initiatives which have rarely fulfilled their potential. The Aid for Trade agenda has offered a practical focal point; in particular due to the light it has shone on regional production networks and associated issues (including different forms of regulatory and infrastructural constraints). There is significant evidence that this has had a real impact. A joint survey by a WTO, African Union/AU and the United National Economic Commission for Africa/UNECA in 2013 found that there had been a major increase in demand for regional aid by organisations in Africa since 2005 (UNECA, AU and WTO, 2013). Of the 2013 trade facilitation case stories, the most cited impacts referred to increased regional trade, (WTO/OECD, 2013: 32). African REC's questionnaire responses are critical of many aspects of existing regional Aid for Trade but they do assert that regional Aid for Trade has been effective in their regions in various sectors including infrastructure development (Southern African Development Community/SADC Secretariat, Communauté Economique et Monétaire d'Afrique Centrale /CEMAC) and productive capacity in different sectors (Economic Community of West African States/ECOWAS Commission and OECS Secretariat), (OECD, 2014b). Regional AfT, and regional integration more generally, is affected by the fact that national interest trumps any conception of regional interest (Byers and Liu, 2013: 16). The regional organisations frequently note a lack of interest from member state administrations in 'regional externalities' but the Aid for Trade agenda offers a practical lever for them to redress this. There are signs that this is having an effect, for example the ECOWAS member states

\footnotetext{
${ }^{16}$ More details can be found here: http://www.afdb.org/en/topics-and-sectors/initiatives-partnerships/aid-for-trade-trustfund/

${ }^{17} \mathrm{http} / / /$ www.itfc-idb.org/content/itfc-announces-\%E2\%80\%9Caid-trade-aft\%E2\%80\%9D-arab-states-initiative
} 
agreed a comprehensive regional Aid for Trade strategy in 2008 (ECDPM, 2010), and such initiatives should help in the long-term process of developing a truly regional approach. Regional organisations frequently report misalignment with donor priorities as well as general coordination problems, meanwhile promising individual programmes have suffered from financial mismanagement (ICAI, 2013). The level of aid is insufficient and the major regional donor, the EU, has aroused resistance and division, with its proposed inter-regional Economic Partnership Agreements. However, undeniably the AfT initiative has made a serious contribution to consolidating regional integration and clarifying priorities.

At the national level, in developing countries, some countries have established AfT strategies, e.g. Mauritius and Jamaica. Others have instituted national co-ordinating mechanisms for AfT. Donor agencies have also developed approaches to AfT, with some having specific plans and strategies, e.g. EU, Finland, Geermany etc. To credit the global monitoring with the sole responsibility for these institutional changes would not be completely fair but it has certainly been a factor. As to whether the AfT agenda has inspired new ways of thinking about trade and development, an in-depth study is beyond the scope of this paper but there is anecdotal evidence that it has had an impact. As a part of the Initiative the UK Department for International Development (DFID) and the Swedish Ministry for Foreign Affairs funded a valuable research project by Overseas Development Institute/ ODI on how to combine AfT with pro-poor/poverty reduction concerns. This provides a methodology for outlining the impact of AfT on different classes of society and programming AfT according to differentiated needs (Higgins and Prowse, 2010). (There is clearly much more work to be done here in combining support for export-led growth and pro-poor aid). Another impact of the AfT agenda can be seen in the debate on the Sustainable Development Goals and the successor to the MDGs. There is a much greater focus on supporting the 'productive sector' than had been the case for the MDGs (UN/OHRLLS 2013: 50; UNICEF 2013: 6), while there remains a consensus on the principles of human development.

The Global monitoring has been flexible enough to adapt to the changing trade and development landscape. For example, the 2013 Aid for Trade at a Glance report examined aid and other official flows as well as other relevant financial flows that make up investment for trade. As non-DAC donors have increased their contribution in recent years particularly in sectors relevant to Aid for Trade, the multilateral context of the WTO has helped to profile these programmes and China and India participated strongly and openly in AfT meetings and were active in the WTO/OECD monitoring work. Given that the Busan High Level Forum's major success was engaging China and other BRICs to sign the outcome document on a voluntary basis, the success of Aid for Trade's engagement with non-DAC donors through the WTO should not be dismissed. Also responses to Questionnaires provide essential insights into how developing countries are responding to emerging challenges such as food insecurity, climate change and natural disasters, as well as opportunities from higher commodity prices, export diversification and connecting to global value chains.

\section{Conclusions}


As ever, the balance sheet on the Aid for Trade review process is mixed. The very broadness of the concept leads to many challenges, both in monitoring flows and in establishing any kind of consensus on the link between development aid and trade. Overall ODA flows remain modest and they are under threat in the post-financial crisis era. Furthermore there are inbuilt tensions between a global agenda such as this and the need for local specificity. Nevertheless there are real achievements to consider. While counterfactuals are problematic, the best estimate is that the AfT process initiated in 2006 has succeeded in raising additional funds. The OECD and WTO have put in place a credible monitoring mechanism which has been refined and expanded over the years. It has drawn in new actors (regional organizations and new donor states) to the process. Notwithstanding the inbuilt tensions in any global process of this kind, the AfT review process has succeeded in rallying political support for Aid for Trade as a global public good. Aid for Trade as a concept has political traction in donor countries (in justifying development aid in an era of austerity) but without this global dimension there is a real danger that Aid for Trade could revert to tied aid. Furthermore, the AfT Initiative is a rare example of emerging donors involving themselves and helping to shape a global development governance initiative which is also strongly supported by the developed world. Such political achievements are not negligible.

The Initiative was initially very successful in rallying resources but recent decisions by the DAC committee have muddled the distinction between ODA and loans of a more commercial nature. This poses a severe challenge to international development aid norms in general, and to the AfT Initiative, but the response to this should be to redouble and improve the AfT monitoring process, rather than abandon it. Hallaert (2013) rightfully asked what's next in monitoring AfT but he incorrectly claimed that the current monitoring approach had reached its limits. Monitoring has not been a passive activity, it has been complemented and reinforced by an active review process - one that promotes change by providing an environment for dialogue, knowledge-sharing, exchange of good practice and information. Hallaert's proposed solution, independent impact evaluation hosted by the World Bank or others is not a substitute for this active review, though it may be a complement and the WTO-led process has been adaptable to involve other actors and bring new knowledge and information to the debate. The concept of a multilateral fund is worth revisiting but it is incumbent on those making this proposal to outline precisely how it would deal with the general challenges to collective action and fund raising. The Bali Agreement offers an example of an accord involving strong quasi-legal commitments by donors, but this is only possible in highly specific circumstances.

Maintaining the momentum of the previous rounds of monitoring will be challenging. Since the Initiative began, there have been calls to have greater private sector involvement but this has proved difficult given the rather weak incentives for the private sector to contribute to a public good like monitoring. New strategic partnerships will be required to ensure a sufficient response rate from private sector actors. The success of this will provide a valuable update on where Aid for Trade stands in the face of the global challenges discussed in the last section. It must be emphasised that these are challenges to development aid in general, not just AfT, and it may be that, due to its political strengths, AfT has a better chance of weathering this storm. As outlined in section 3, global 
development governance is inherently problematic but the AfT Initiative can lay claim to being one of the more successful examples of this ideal. Its light touch approach to its topic was the most realistic option and it can develop further, with political will. The issues brought out during this Initiative are clearly resonating in the discussions on the Post-2015 global development agenda and the United Nations' Task Team Report gives strong support to the broader Aid for Trade agenda (United Nations' System Task Team, 2013: 5, 13). Whatever the future of the Initiative it offers valuable lessons for future global co-operation models. 


\section{References}

Adhikari, R. (2011) 'Evaluating Aid-for-Trade Effectiveness on the Ground: A Methodological Framework'. Geneva and Kathmandu: ICTSD and South Asian Watch on Trade, Economy, and Environment. (accessed 28 April 2014).

AfDB/African Development Bank Group, (2012), Aid for Trade Trust Fund, http://www.afdb.org/en/topics-andsectors/initiatives-partnerships/aid-for-trade-trust-fund/ (accessed 28 April 2014).

African Development Bank/ADB 2006) 'Aid for Trade Task Force - Communication from the African Development Bank' WT/AFT/W/7

https://docs.wto.org/dol2fe/Pages/FE_Search/FE_S_S006.aspx?Query=(\%20@Symbol=\%20wt/aft/*\%20)\&Lan guage=ENGLISH\&Context=FomerScriptedSearch\&languageUIChanged=true\# (accessed 29 April 2014).

Axelrod, R. (1997) 'Promoting Norms: An Evolutionary Approach to Norms', in Axelrod (ed.) The Complexity of Cooperation, Princeton: Princeton University, pp. 44-68.

Basnett, Y. Engel, J. Kennan, J. Kingombe, C. Massa, I. and te Velde, D.W. (2012) 'Increasing the effectiveness of Aid for Trade: the circumstances under which it works best' ODI Working Paper 353

Basnett, Y. (2011) 'Taking stock of Aid for Trade' ODI blog post, http://www.odi.org.uk/opinion/5871-takingstock-aid-trade (accessed 28 April 2014).

Byers, B. and D. Liu, (2013) 'Regional Aid for Trade Effectiveness and Corridors', June 2013, ODI/ECDPM Report. http://www.odi.org.uk/sites/odi.org.uk/files/odi-assets/publications-opinion-files/8464.pdf (accessed 28 April 2014).

Byers, B. (2013) 'The Aid for Trade Fourth Global Review: Aid to Productive Employment', ECPDM Talking Points Blog,

https://ecdpm.org/talking-points/the-aid-for-trade-4th-global-review-aid-for-productive-employment/ (accessed 28 April 2014).

Cadot, O. Fernandes, A.M. Gourdon, J.and Mattoo, A. (2011) (eds) 'Where to Spend the Next Million? Applying Impact Evaluation to Trade Assistance' Washington, DC: World Bank

Chandy, L. and Kharas, H. (2011) 'Why Can't We All Just Get Along? The Practical Limits to International Development Cooperation’ Journal of International Development, Vol. 23 (5), pp. 739-751.

Checkel, J.T. (2001) 'Why comply? Social learning and European identity change' International Organization 55, pp. 553-588.

Cox, R. (1986) 'Social Forces, States and World Order: Beyond International Relations Theory', in Keohane (ed.) Neorealism and its critics, New York: Columbia University Press pp. 204-250.

DIIS/Danish Institute for International Studies. The Evaluation of the Paris Declaration, Final Report, Copenhagen, May 2011

ECDPM/ European Centre for Development Policy Management. (2010) The EU Commitment to Deliver Aid for Trade in West Africa and Support the EPA Development Programme (PAPED), No. 96 May 2010. Available from: 
http://www.ecdpm.org/Web_ECDPM/Web/Content/Download.nsf/0/F7D8B664ACE0F5ACC125771C002CAF

BB/\$FILE/10-96\%20final\%20may\%2018.pdf (accessed 19 March 2012).

Evenett, S. (2005), "Some tough love on 'Aid for Trade"', Intereconomics, Vol. 40, No. 6, November/December 2005, pp.326-329.

Finnemore, M. (1996) 'Norms, Culture, and World Politics: Insights from Sociology's Institutionalism' International Organization Vol. 50, pp. 325-347.

Finnemore, M. and K. Sikkink (1998) 'International Norm Dynamics and Political Change', International Organization, Vol. 52(4), pp. 887-917.

Haas, P. (1989) 'Do Regimes Matter: Epistemic Communities and Mediterranean Pollution Control',

International Organization, Vol. 43, pp.377-403.

Hallaert, J. J. (2013) 'The future of Aid for Trade: challenges and options', World Trade Review, 12 (4), 653668.

Hasenclever, A., Mayer, P. and V. Rittberger (1997) Theories of International

Regimes, Cambridge: Cambridge University Press.

Higgins, K. and S. Prowse (2010) 'Trade, Growth and Poverty: Making Aid for Trade Work for Inclusive Growth and Poverty Reduction,' Working Paper 313, London: ODI.

Hoekman, B. (2002) 'Strengthening the Global Trade Architecture for Development', World Bank Policy

Research Working Paper No. 2757, Washington DC: World Bank.

Hoekman, B. and Prowse S. (2005) Economic Policy Responses to Preference Erosion: From Trade as Aid to Aid for Trade, PRSP 3721. Washington DC: World Bank.

Hoekman, B. and Wilson, J. (2010) ‘Aid for Trade: Building on Progress Today for Tomorrow's Future', Policy Research Working Paper 5361 Washington DC: World Bank.

Holden, P. (2009) In Search of Structural Power: EU Aid Policy as a Global Political Instrument, Farnham: Ashgate.

Hynes, W. and S. Scott (2013) 'The Evolution of Official Development Assistance: Achievements, Criticisms and a Way Forward, Development Co-operation Working Paper No. 12, Paris: OECD

ICAI/ Independent Commission for Aid Impact (2013) 'DFID's Trade Development Work in Southern Africa', Report No 30 - December 2013.

http://icai.independent.gov.uk/wp-content/uploads/2013/12/DFIDs-Trade-Development-Work-in-Southern-

Africa-Report.pdf (accessed 28 April 2014).

IsDB/International Islamic Trade Finance Corporation (2012), Summary of New Initiative, <http://www.itfcidb.org/content/itfc-announces-\%E2\%80\%9Caid-trade-aft\%E2\%80\%9D-arab-states-initiative>. (accessed 28 April 2014).

Kharas, H. (2010) The Hidden Aid Story: Ambition Breeds Success Washington DC: Brookings Institution.

Krasner S. D. (1999) Sovereignty: Organized hypocrisy, Princeton, NJ: Princeton University Press.

Langan, M. and Scott, J. (2011) 'The False Promise of Aid for Trade'. Working Paper 160. Manchester: BWPI.

Laird, S. (2007) ‘Aid for Trade: Cool Aid or Kool-Aid?’ G-24 Discussion Paper No. 48. Geneva: UNCTAD 
Lightfoot, S. J. and S. Kim (2011) 'Does DAC-ability matter? The emergence of Non-DAC donors', Journal of International Development 23 .5: 711-721.

Manning, R. (2006) 'Will "Emerging Donors" Change the Face of International

Cooperation?' Development Policy Review Vol. 24 (4), pp. 371-385.

Neilson, J. (2005) 'Aid for Trade' in R Newfarmer (ed.) Trade, Doha and Development; A Window into the Issues, Washington DC: World Bank.

OECD (2006a) Aid for Trade: Making it Effective, Paris: OECD.

OECD (2006b) Aid for Trade: Funding for an Expanding Agenda, Paris: OECD.

OECD (2008a) Improving the Monitoring of Aid for Trade, Paris: OECD.

OECD (2008b) Monitoring Aid for Trade: A Background Note, Paris: OECD.

OECD (2009) Aid for Trade at a Glance, Paris: OECD.

OECD (2011a) Aid Effectiveness 2005-2010: Progress in Implementing the Paris Declaration, Paris: OECD.

OECD (2011b) OECD report on division of labour: addressing cross-country fragmentation of aid www.oecd.org/dac/aideffectiveness/49106391.pdf (accessed 28 April 2014).

OECD (2011c) Strengthening Accountability in Aid for Trade, Paris: OECD.

OECD (2013) Development at a Glance: Statistics by Region, Paris: OECD.

OECD (2014a) 'Aid for Trade in 2012: Increasing Volumes, Hardening Terms', Communication from the OECD to the WTO Committee on Trade and Development

OECD (2014b) Regional Approaches to Aid for Trade, Paris: OECD.

OECD/WTO (2007) Aid for Trade 1st Global Review, Paris: OECD.

OECD/WTO (2009) Aid for Trade at a Glance 2009: Maintaining Momentum, Paris: OECD.

OECD/WTO (2011) Aid for Trade at a Glance 2011: Showing Results, Paris: OECD.

OECD/WTO (2013) Aid for Trade at a Glance 2013: Connecting to Value Chains, Paris: OECD.

Pagani, F. (2002), 'Peer Review as a Tool for Co-operation and Change. An Analysis of an OECD Working Method', African Security Review Vol. 11 (4), pp. 15-24.

Page, S. (2005), 'A Preference Erosion Compensation Fund: A new proposal to protect countries from the negative effects of trade liberalisation' Overseas Development Institute, Opinions 35, http://www.odi.org.uk/publications/opinions/35_preference_erosion_jan05.html (accessed 28 April 2014).

Page, S. (ed) (2006), Trade and Aid: Partners or Rivals in Development Policy? London: Cameron.

Page, S. (2007), 'The Potential Impact of the Aid-for-Trade Initiative'. G-24 Discussion Paper 45.

Geneva: UNCTAD

Paulo, S. and H. Reisen, (2010) 'Eastern Donors and Western Soft Law: Towards a DAC Donor Peer Review of China and India?' Development Policy Review, Vol. 28 (5), pp. 535-552.

Prowse, S. (2006) 'Aid for trade - increasing support for trade adjustment and integration - a proposal', id 21 insights no.59 (December), Institute of Development Studies, University of Sussex

Ravenhill, J. (2014) 'Global value chains and development', Review of International Political Economy, Vol 21 (1),pp. 264-274. 
Reddy, S. and Heuty, A. (2008), 'Global Development Goals: The Folly of Technocratic Pretensions', Development Policy Review, Vol. 26 (1), pp. 5-28.

Risse, T., Ropp, S. and K. Sikkink (1999), The Power of Human Rights: International Norms and Domestic Change, Cambridge: Cambridge University Press

Rogerson, A. and B. Killen (2010), ‘Global governance for international development : who's in charge?’ OECD DCD-DAC development brief consultation draft. Issue 2, 2010.

http://www.oecd.org/development/aideffectiveness/45569897.pdf (accessed 28 April 2014).

Saana Consulting (2014) Evaluation of the OECD Development Assistance Committee contributions with the Trade Committee to the WTO-led Aid for Trade Initiative',

http://www.oecd.org/development/aft/OECD\%20AfT\%20Final\%20Report\%20Submitted.pdf _ (accessed 28 April 2014).

Schofield, J. (2001) 'Time for a revival?: Public Policy Implementation: A review of the literature and an agenda for future research', International Journal of Management Reviews, Vol. 3, pp. 245-263.

Schraeder, P. Hook, S. And B. Taylor, (1998) ‘Clarifying the Foreign Aid Policy’, World Politics Vol. 50 (1), pp. 294-323.

Stiglitz, J. and A. Charlton (2012) 'The Right to Trade: A Report on the Commonwealth Secretariat on Aid for Trade'

<http://unctad.org/meetings/en/Miscellaneous\%20Documents/Right-to-Trade-Report.pdf>.

Stiglitz, J. and A. Charlton, (2006) 'Aid for trade', International Journal of Development Issues, Vol. 5 (2), pp. $1-41$.

United Nations (2012) UN Inter-Agency Cluster on Trade and Productive Capacity: Delivering on Aid for Trade, UNCTAD: Geneva http://unctad.org/en/PublicationsLibrary/tc2010d1rev3_en.pdf (accessed 28 April 2014).

UNICEF (2013) Key Messages on the Post-2015 Development Agenda, http://www.unicef.org/post2015/files/Post 2015 Key Messages V07.pdf

(accessed 26 November 2014)

United Nations System Task Team (2013) 'A renewed global partnership for development', New York: UN.

UNECA, AU and WTO, (2013) Building Trade Capacities for Africa's Transformation

http://www.wto.org/english/tratop_e/devel_e/a4t_e/global_review13prog_e/gr4_rep2013_e.pdf (accessed April 2014).

UN/OHRLLS (2013) State of the Least Developed Countries 2013 Follow up of the Implementation of the Istanbul Programme of Action for the Least Developed Countries http://unohrlls.org/custom-content/uploads/2013/10/State-of-the-LDCs-2013.pdf (accessed 26 November 2014)

UNIDO (2011) Trade Capacity Building Resource Guide 2010, Vienna: UNIDO

UNIDO (2013) Trade Capacity Building Resource Guide 2013, Vienna: UNIDO

Wilkinson, R. (2006) The WTO crisis and the governance of international trade, London: Routledge. 
Woods, N. (2008) 'China, Emerging Donors and the Silent Revolution in Development Assistance', International Affairs Vol. 84 (6), pp. 1-18.

World Bank/IMF (2005) Doha Development Agenda and Aid for Trade, Joint Paper presented to the Development Committee, September 12 2005, http://www.oecd.org/trade/aft/35590809.pdf

WTO (2006a) Aid For Trade: Concept Paper And Timeline for 2006.

WTO (2006b) Aid for Trade Taskforce, Recommendations, 27 July 2006.

WTO (2006c) Update on Aid for Trade, Internal WTO Secretariat Note, June 2006

WTO (2006d) An Enhanced Integrated Framework: Report of the Chairman of the Task Force on an Enhanced Integrated Framework, including Recommendations, WT/IFSC/W/15, Geneva: WTO

Young, O. R. ed. (1999) The Effectiveness of International Environmental Regimes: Causal Connections and Behavioral Mechanisms. Cambridge: MIT Press.

Zambian Government (2006) 'Aid for Trade Task Force - Communication from Zambia on behalf of the LDC Group - Aid for Trade - An LDC Perspective' WT/AFT/W/22

https://docs.wto.org/dol2fe/Pages/FE Search/FE S S006.aspx?Query=(\%20@ Symbol=\%20wt/aft/*\%20)\&Lan guage=ENGLISH\&Context=FomerScriptedSearch\&languageUIChanged=true\# (accessed 29 April 2014). Zedillo, E., Messerlin, P. and Neilson, J. (2005) Trade for Development. UN Millennium Project Task Force on Trade, London: Earthscan. 
RESEARCH

FACULTY OF

WITH

BUSINESS

PLYMOUTH

MTH

UNIVERSITY

PLYMOUTH 
RESEARCH

FACULTY OF

WTH

BUSINESS

PLYMOUTH

MTH

UNIVERSITY

PLYMOUTH 